\title{
Limitations of E-commerce implementation in developing countries: Case study of Iran
}

\author{
${ }^{1}$ Shahram Mohanna (PhD), ${ }^{2}$ Nour Mohammad Yaghoubi (PhD), ${ }^{3}$ Samane Vahidi Motlaq \\ and ${ }^{3 *}$ Tayebe Vahidi Motlaq \\ ${ }^{1}$ Faculty of Electrical and Computer Engineering, University of Sistan and Baluchestan, Iran \\ ${ }^{2}$ Faculty of Management and Accounting, University of Sistan and Baluchestan, Iran \\ ${ }^{3}$ Master student of Information Technology, University of Sistan and Baluchestan, Iran \\ "Corresponding author
}

\begin{abstract}
Electronic Commerce (E-Commerce) is well-accepted in the developed world and is playing a vital role in economic development. The less-developed and developing nations are far behind in this regard, despite of the fact that the governments have had attempted to encourage ECommerce. This paper explores the factors which can act as constraints to the development of E-Commerce in Iran. A qualitative and quantitative study was conducted in Sistan Baluchestan province of Iran. In the procedure, the professionals were interviewed while the responses of the business experts were elicited by questionnaire. According to our findings, technical infrastructure, managerial-organizational factors have supported the E-Commerce in Iran. However, social-cultural backgrounds were identified as the main barriers to E-Commerce implementation in the country. The results show that, low IT literacy rates, insignificant demand for on-line business and e-trust among the traditional traders are the major limitation aspects. In order to improve the state of E-Commerce in the country, the cultural barriers will need to be overcome. This can be achieved through mass education people to understand and accept the new technologies including IT and E-Commerce.
\end{abstract}

Keywords: electronic commerce, IT infrastructure, managerial and social infrastructure

\section{INTRODUCTION}

Electronic commerce is a process of buying and selling products, services and information using computer networks and the internet. E-Commerce accelerates global commercial trend by removing the boundaries facing international trade. It benefits from economic advantages such as market expansion, reduction of product source prices, promotion of productivity, reduction of transaction costs and inflation, lowering uncertainty, sharing market information, and aiding in distribution channel efficiency and plays a vital role in an endogenous economic growth [1]. E-Commerce can be a source that improves domestic economic and rapid globalization of production, and development of available technology [2]. Africa and the Middle East suffer from very specific issues that need to be integrated into world agenda and agreements taking place where, the barriers are very well understood and have been researched by many $[1,3,4]$. In the literatures published on E-Commerce in developing countries the assumption is that Internet access will enhance E-Commerce in these countries [1,2], however in most developing countries there are several barriers in expanding E-Commerce including basic resources, lack of infrastructure, environmental factors, education and cultural problems[3, 4, 5,6].

An important requisite for increasing the use of $E$ Commerce is traders and users' adoption along with social-cultural backgrounds such as high-skilled labor and IT literacy among traders and consumers [9]. A number of different E-Commerce adoption barriers have been documented in research studies. Some of these include the high costs associated with ECommerce, the lack of technical resources and expertise to apply E-Commerce, the difficulty of ECommerce technology and the complexity of measuring the return on investment [10]. Since 1995, Iran has enjoyed a dramatic increase in IT adoption. This development has fostered an excellent environment for expansion of IT in the country. However, E-Commerce expansion rate was moderate or low. In other word E-Commerce is lagging behind and need to invest more for 
development of E-Commerce. The country invests heavily on spread of internet and Electronic Banking (e-banking) among governmental institutions and private sectors in compare with other middle-east countries $[5,7,8]$. A study of implementation of ECommerce in Iranian SMEs carried out, indicating that factors like development, education and management of human resources, production scheduling, foreign relations management, communications systems and financial management are among the important critical failure factors [11, 12]. A research in 2008 was shown that incomparable managerial decision and luck of unique vision among the organizations in Iran are one of barriers of the progress of E-Commerce in the country [5].

As technical infrastructures, managerial factors and social background play different role in every country, therefore it is necessary to re-examine these important factors in Iran as well. To determine the situation of E-Commerce in a country, some factors need to be examined including; the government, business, consumers, and technical infrastructure as well as social and cultural background. This paper is an attempt to identify reasons behind the slow progress of E-Commerce in developing countries mainly in Iran.

Research method: Most of the above mentioned factors that act as barriers to growth of E-Commerce in developing countries are investigated in Iran circumstances.

Conceptual model and hypotheses: A qualitative assessment, using interviews with IT professionals, was performed. The results as well as, literature reviews summarized in previous section, conclude that the barriers and limitations of E-Commerce in Iran can be categorized into three main groups, including managerial -organizational factors, technical infrastructure and social-cultural background. Figure 1 shows the conceptual model for this study.

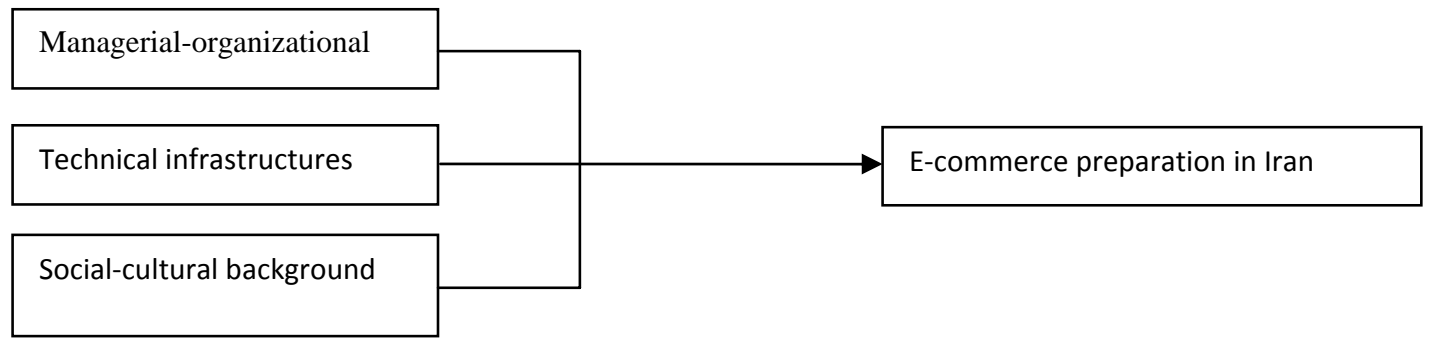

Fig 1: conceptual model

The hypothesis in this survey includes three assumptions:

$\mathrm{H} 1$ : The managerial and organizational factors support E-Commerce in Iran.

$\mathrm{H} 2$ : The technical infrastructures Iran are prepared for E-Commerce in Iran.

H3: The Social-Cultural backgrounds of people in Iran are ready for E-Commerce.

\section{Data Collection}

The Instrument Validity and Reliability: In order to remain consistent with prior studies reviewed in section 1, measures were adopted from previous, ECommerce acceptance, online shopping, and other previous studies and associated theories. A questionnaire including 15 measures were utilized in which, responses were measured by a 5-point Likert- type scale ( 1 strongly disagree; 2 disagree; 3 neutral; 4 agree; 5 strongly agree). In order to validate the instrument, twenty Iranian IT experts were interviewed. Therefore, some modifications were made to the questionnaire, on the basis of the comments collected throughout this pilot study. After the pilot study, a pre-test was conducted on 30 randomly selected merchant with E-Commerce experience. Feedback was acquired with regard to the length of the instrument, the format of the scales, content validity, and question clarity. On the basis of that feedback, minor modifications were performed, after these modifications the final questionnaire was designed. All of the measurement scales have an acceptable level of reliability, with Cronbach alpha coefficients greater than 0.80 .

The sample group: The sample statistic society of this research included all merchants of Sistan and Baluchestan province of Iran, who have international 
import/export activities. An invitation letter was sent to every person called for participating in a training session. The number of 94 traders and business experts took part in the session got the questionnaires which, only 80 persons collaborate and replied. From the population about $\% 74$ were men and \%26 were women being \%80 undergraduate and $\% 20$ postgraduate.

\section{Correlation analysis}

The results of analyzing data in this research was performed employing T-Student Test in which, the error level of Alpha was set to 0.05 and the Degree of Freedom was set to $79(\mathrm{DF}=79)$. These parameters were used for assessment and testing the research Hypotheses. The statistic results are shown in Table 1. Also the ranking of the three hypotheses is presented in Table 2.

Table 1: one - sample T- test

\begin{tabular}{|c|c|c|c|c|c|c|}
\hline & \multicolumn{6}{|c|}{ Test Value $=3$} \\
\hline & & & & & $\begin{array}{l}\text { 95\% Confidence } \\
\text { Differ }\end{array}$ & val of the \\
\hline & $\mathbf{T}$ & df & $\begin{array}{l}\text { Sig. (2- } \\
\text { tailed) }\end{array}$ & $\begin{array}{c}\text { Mean } \\
\text { Difference }\end{array}$ & Lower & Upper \\
\hline H1 & -.380 & 79 & .705 & .02500 & -.1558 & .1058 \\
\hline $\mathrm{H} 2$ & .388 & 79 & .699 & .03437 & -.1422 & .2109 \\
\hline H3 & -33.83 & 79 & .000 & -1.43 & -1.51 & -1.34 \\
\hline
\end{tabular}

Table 2: Ranking of the research hypotheses

\begin{tabular}{|lcc|}
\hline Supported infrastructure & Average of the ranking & Final ranking \& importance \\
\hline Technical infrastructures( $\mathrm{H} 2)$ & 3.03 & 1 \\
\hline $\begin{array}{l}\text { Managerial-Organizational Factors } \\
\text { (H1) }\end{array}$ & 2.97 & 2 \\
\hline Social-Cultural background $(\mathrm{H} 3)$ & 1.57 & 3 \\
\hline
\end{tabular}

T-test result: It can be depicted from Table 1 that, the value of Sig or $\mathrm{P}$-value for $\mathrm{H} 1$ is equal to 0.705 which is larger than $\alpha=0.05$ so $\mathrm{H} 1$ is accepted indicating the technical infrastructure for ECommerce in Iran Supports E-Commerce based on the view of the sample group. Additionally, the T-test analysis points out $\mathrm{H} 2$ is accepted too, showing management and organization factors could support E-Commerce in Iran. The last row of the table illustrate that, Sig or P-value for $\mathrm{H} 3$ is equal to 0.00 , signifying the social- cultural background of people in Iran is far behind of accepting E-Commerce.
A deep analysis performed to order the 15 measures in the questionnaire based on the sample group grades. The result is presented in Table 3.

As can be depicted from Table 3, among the technical infrastructure, the logistics factor got the lowest score concerning transportations, postal and delivery speed is not adequate to support ECommerce in Iran. Additionally, the table shows that, the legal issues are far behind to support ECommerce and encourage the citizens to use the technology. Furthermore, within the cultural-social factors IT literacy takes the lowest score and e-trust also is next to last. 
Am. J. Sci. Ind. Res., 2011, 2(2): 224-228

Table 3: Ranking of the research factors

\begin{tabular}{|l|l|c|c|}
\hline $\begin{array}{l}\text { Supported } \\
\text { infrastructures }\end{array}$ & Infrastructure`s factors & $\begin{array}{c}\text { Average of } \\
\text { the Score }\end{array}$ & $\begin{array}{c}\text { Final } \\
\text { ranking }\end{array}$ \\
\hline Technical & S1:experts of IT in Iran & 3.32 & 1 \\
reinfrastructu & S2:speed of internet & 3.25 & 2 \\
& S3:internet connectivity & 2.82 & 3 \\
& S4: E-Commerce public database & 2.74 & 4 \\
& S5: Logistics & 2.48 & 5 \\
\hline Managerial - & S6:government IT investment & 3.38 & 1 \\
organizational & S7:specific strategy for international E-Commerce & 3.10 & 2 \\
Factors & S8:creating E-Commerce section in trading department & 2.92 & 3 \\
& S9:managers commitment & 2.75 & 4 \\
\hline Social-cultural & S10: ambiguity and legal issues & 2.70 & 5 \\
background & S11:E-Commerce training & 1.68 & 1 \\
& S12:cultural acceptance of E-Commerce & 1.66 & 2 \\
& S13 awareness about E-Commerce & 1.57 & 3 \\
& S14:trust in E-Commerce services & 1.56 & 4 \\
\hline
\end{tabular}

\section{DISCUSSIONS}

Development of E-Commerce is highly depends on the levels of technical, managerial, economic, social, cultural and political aspects. In this study our focus was on technical infrastructure, managerialorganizational factors and cultural-social background. According to our finding technical infrastructure and managerial-organizational factors have better situation respectively and almost supported the ECommerce in Iran. However, cultural and social background of the people lags in term of accepting ECommerce in Iran. Among cultural and social factors IT literacy takes the lowest score and e-trust also is next to last. Therefore, the government, the private sectors and the media need to invest in E-Commerce training programs. In addition, the government should plan to modify the law to embrace E-Commerce and increase e-trust among Iranians.

\section{CONCLUSIONS:}

To sum up, our empirical findings show that, the concern of E-Commerce implementation in Iran is not the same as the case in developing and undeveloped countries. According to our finding technical infrastructure and managerial-organizational factors almost support E-Commerce in Iran, although the cultural and the social background of the citizens lags in term of accepting E-Commerce in Iran. Among cultural and social factors, IT literacy takes the lowest score and e-trust also is next to the last so the government and the private sectors working in the commercial activities needs to invest in special training programs. Finally, modification of the law toward supporting E-Commerce activities is a key increasing e-trust.

\section{REFERENCES}

1- Molla, A., Taylor, R. \& Licker, S., (2006). ECommerce Diffusion in Small Island Countries: the Influence of Institution in Barbados. The Electronic Journal of Information Systems in Developing Countries, 28(2),pp. 1-15.

2- Sheth, J. N., \& Sharma, A., (2005). International emarketing: Opportunities and issues. International Marketing Review, 22(6), pp. 611-622.

3- A. Molla and P.S. Licker, (2005). Perceived EReadiness factors in E-Commerce adoption: An empirical investigation in a developing country, International Journal of Electronic Commerce 10 (1) ,pp. 83-110.

4- Travica, B., (2002). "Diffusion of electronic commerce in developing countries: The case of Costa Rica, Journal of Global Information Technology Management, 5(1), pp. 4-24.

5- - I. Nakhai Kamalabadi, A. Bayat, P. Ahmadi and A. Ebrahimi,( 2008). Identifying and Prioritization of Challenges and Barriers of E-Commerce Implementation in Iran, World Applied Sciences Journal, 5(5), pp. 590-597.

6- Gibbs, J., Kraemer, K. \& Dedrick, J. (2003). Environment and policy factors shaping E- 
Am. J. Sci. Ind. Res., 2011, 2(2): 224-228

Commerce diffusion: a cross country comparison. The Information Society, 19, pp. 5-18.

7- Mohammad Ali Sarlak, Asghar Abolhasani Hastiani, ( 2008). E-Business Barriers in Iran's Free Trade Zones, Journal of Social Sciences 4 (4),pp. 329-333.

8- M.A. Sarlak, A.R. Aliahmadi, A.Ghorbani and M. Shahidi, (2009). Recognition of Factors Affecting the Successful Implementation of ElectronicBanking in Iran, Journal of applied Sciences 9 (21), pp. 3821-3828.

9- Alireza Abbasi ,(2008). A Strategic Plan for ECommerce Development in Iran, Third International Conference on Convergence and Hybrid Information Technology,pp.32-41.
10- Robert C. MacGregor, Lejla Vrazalic,( 2005). A basic model of electronic commerce adoption barriers, Journal of Small Business and Enterprise Development , 12(4), pp. 510-527.

11- Yasser Amiri, Habibollah Salarzehi ,( 2010). Fuzzy Sketch for Implementation of E-Business Plan in Iran SMEs, International Business Research , 3(4), pp. 172-180.

12- Shaaban Elahi, Alireza Hassanzadeh, (2009). A framework for evaluating electronic commerce adoption in Iranian companies, International Journal of Information Management, 29( 1), pp. 27-36. 